\title{
Maria D'Alva Gil Kinzo
}

Argelina Cheibub Figueiredo

\begin{abstract}
trajetória de Maria D’Alva Gil Kinzo se confunde com o desenA volvimento de uma área central da ciência política brasileira: partidos políticos e eleições. Sua contribuição para o avanço do conhecimento nesse campo é ímpar. Em trabalho precursor da importância que passaria a ter a legislação eleitoral no debate institucional, inicia sua carreira com uma dissertação de mestrado sobre representação política e sistema eleitoral no Brasil. Seu pioneirismo se revela mais uma vez em sua tese de doutorado - um estudo sobre o papel do Movimento Democrático Brasileiro - MDB, como organização política, no regime autoritário-, defendida no ano em que o Partido do Movimento Democrático Brasileiro - PMDB assume o primeiro governo civil. Em sua volumosa obra, pesquisa múltiplas dimensões do comportamento eleitoral e da vida partidária brasileira; analisa o processo de transição e as características da democracia brasileira; examina e discute alternativas institucionais diversas para o aperfeiçoamento da democracia no Brasil.
\end{abstract}

A contribuição de D'Alva Kinzo na institucionalização e no fortalecimento da ciência política brasileira, porém, não se limita à sua produção individual. Deixou também sua marca nos mais diversos espaços em que atuou. Professora dedicada e orientadora rigorosa, fez escola; como pesquisadora, foi fonte geradora de novos conhecimentos e formadora de novas gerações. Na Associação Nacional de Pós-Graduação

DADOS - Revista de Ciências Sociais, Rio de Janeiro, Vol. 51, nํ2, 2008, pp. 269 a 270. 
e Pesquisa em Ciências Sociais - Anpocs e na Associação Brasileira de Ciência Política - ABCP, fez de sua liderança um exemplo para colegas e estudantes. Reconhecida internacionalmente, usou sua influência para organizar seminários e coletâneas sobre o Brasil, contribuindo assim para difundir o conhecimento sobre o país e, ao mesmo tempo, divulgar a produção nacional no exterior.

Perseverante e obstinada, alegre e vivaz, D'Alva fez tudo isso de forma aguerrida, mas ao mesmo tempo delicada e meiga. Como cientista política fará falta. Como pessoa, amiga, deixa muita saudade. 